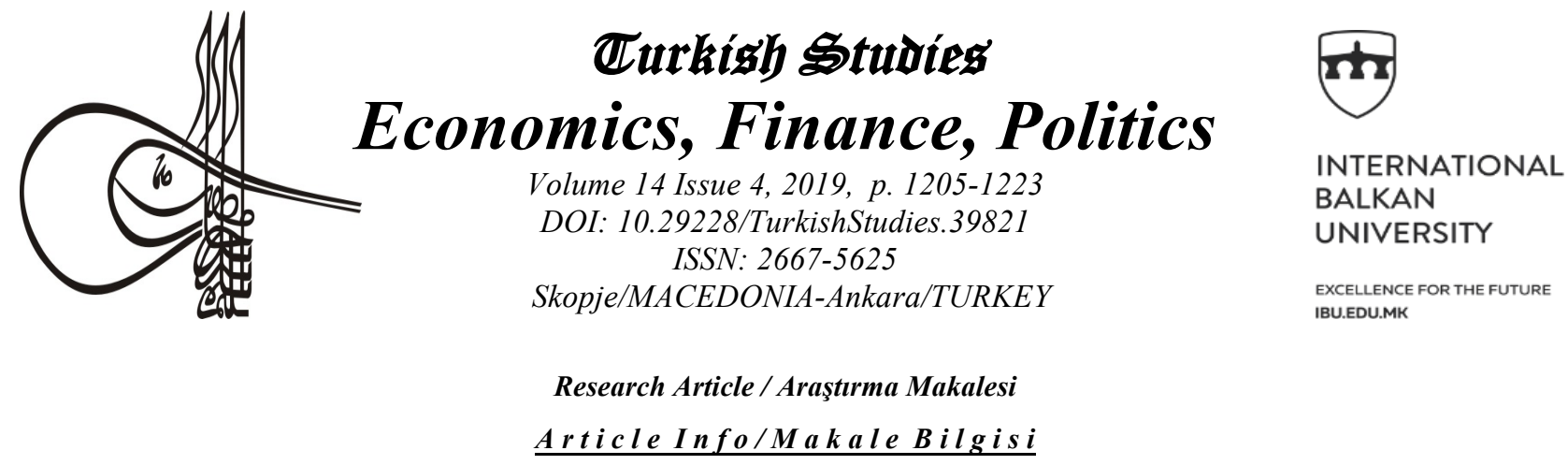

Received/Geliş: 19.11.2019

$\checkmark$ Accepted/Kabul: 20.12.2019

Go Report Dates/Rapor Tarihleri: Referee 1 (28.11.2019)-Referee 2 (29.11.2019)

This article was checked by iThenticate.

\title{
FİNANSAL VE MALİ TABLO OKURYAZARLIĞI: TUNCELI'DE TİCARETLE UĞRAŞAN VERGİ MÜKELLEFLERİNE YÖNELIKK BİR UYGULAMA
}

\author{
Birgül BOZKURT YAZAR* - Zülkif YALÇIN**
}

\begin{abstract}
Öz
Günümüz koşullarında birçok gerçek ve tüzel kişiler finans alanında çok fazla faaliyet göstermektedir. Bu faaliyetler çoğu zaman kredi çekerek, varlık alarak, yatırım yaparak karşımıza çıkmaktadır. Finans alanında bu kadar faaliyet olmasına rağmen bu gerçek ve tüzel kişiler yapmış olduğu faaliyet hakkında çok fazla bilgi sahibi olamamaktadır. Bunun sebebi ise finans ve mali tabloların uzman olan kişiler tarafından anlaşılabilir olmasıdır. Bunun yanında özellikle mali tabloların teknik ve uygulama yönünün olması anlaşılmayı biraz daha zorlaştırmaktadır. Ancak finansal ve mali tablo okuryazarlığ günümüzdse finans sektörünün çok gelişmesi ve bu alanda faaliyetlerin artması sebebiyle önem kazanmıştır. Bu noktada birçok araştırma yapılmış ve çalışma yayınlanmıştır. Bilime bu anlamda katkı sunmak amacıyla Tunceli ilinde ticaretle uğraşan vergi mükelleflerinin finansal ve mali tablo okuryazarlık düzeyleri belirlenmeye çalışılmıştır. Çalışmamızın amacı ticaretle uğraşan gerçek ve tüzel kişilerin finansal ve mali tablo okuryazarlık düzeyinin belirlenmesini sağlamaktadır. Çalışmamızda ticaretle uğraşan gerçek ve tüzel kişileri seçmemizdeki amaç bu kişilerin finans sektörü ile daha fazla çalışıyor olmasıdır. Çalışma dört bölümden oluşmaktadır. Çalımamızın birinci bölümünde finansal okuryazarlık ile ilgili genel bilgiler; ikinci bölümünde mali tablo okuryazarlığ 1 ile ilgili genel bilgiler; üçüncü bölümünde finansal ve mali tablo okuryazarlık ilişkisi hakkında bilgi verilmiş ve son olarak dördüncü bölümünde Tunceli ilinde ticaretle uğraşan vergi mükelleflerine yönelik uygulamaya yer verilmiștir. Çalışma ile Tunceli ilinde ticaretle uğraşan vergi mükelleflerinin finansal davranışlarının
\end{abstract}

Dr. Öğr. Üyesi, Munzur Üniversitesi, E-posta: birgulbozkurt@munzur.edu.tr.

** ID Dr. Öğr. Üyesi, Munzur Üniversitesi, E-posta: zulkifyalcin@gmail.com. 
yarattığı sonuçların işletme performansı ve sürekliliğine etkisinin ortaya konması amaçlanmaktadır. Çalışmada veri toplama yöntemi olarak ikincil kaynak taraması yapılmıștır. Çalışmanın uygulama kısmında yer alan anketin değerlendirilmesinde SPSS paket programı kullanılmıştır.

Anahtar Kelimeler: Finansal Okuryazarlik, Mali Tablo Okuryazarlığı, Finansal Davranış

\title{
FINANCIAL AND FINANCIAL STATEMENT LITERACY: AN IMPLEMENTATION FOR TAX PLAYERS DEALING IN TRADE IN TUNCELI
}

\begin{abstract}
In today's conditions, many real and legal persons are active in the field of finance. These activities are often seen by attracting loans, taking assets and making investments. Real and Legal Persons Although they are so active in the field of Finance, they do not know much about their activities. The reason for this is that the financial and financial statements can be understood by experts. In addition, the technical and practical aspects of financial statements make it more difficult to understand. However, financial literacy and financial statement literacy has gained importance due to the very development of financial sector and increasing activities in this field. At this point, many researches and studies have been published. In order to contribute to science in this sense, the financial literacy and financial statements literacy levels of the taxpayers engaged in trade in Tunceli province were tried to be determined. The aim of our study is to determine the level of literacy of financial and financial statements of real and legal persons engaged in trade. The purpose of our study is to select real and legal persons engaged in trade and to work more with the financial sector. The study consists of four parts. In the first part of our study, general information about financial literacy; In the second part, general information about financial statements literacy; In the third section, information on the relationship between financial literacy and financial statements literacy is given and finally in the fourth section, the application for the taxpayers engaged in trade in the province of Tunceli is given. The aim of this study is to reveal the effects of the financial behaviors of taxpayers engaged in trade in Tunceli province on business performance and continuity. In the study, secondary source scanning was performed as data collection method. SPSS package program was used in the evaluation of the questionnaire in the application part of the study.
\end{abstract}

\section{STRUCTURED ABSTRACT}

In today's conditions, real and legal persons have many relations with the financial sector. This relationship is often seen as attracting loans, investing (stocks, bills or bonds), buying or renting assets. However, these people do not have information about the other activities of this sector, such as many terms and operations. For example, when offering loans to people, it presents interest rates on a monthly basis, 
but when opening a term account and giving interest, it presents the interest rate annually. When people do not know this distinction, they will be affected by misleading rates. Trade has always been in close contact with the financial sector. Because the most challenging in the financial field is the people engaged in trade. These people are also most affected by the deterioration of the economic balance. Therefore, it is important whether the persons operating in this field are successful in understanding financial terms and transactions and financial statements. Our study gains importance in this sense. Our study was conducted on people who are engaged in commerce in Tunceli Province by conducting research in a narrow area. The aim of our study is to determine the level of literacy of financial literacy and financial statements of real and legal persons engaged in trade in Tunceli Province.

Financial literacy; as a result of the trainings they receive, individuals can make financial initiatives, use the funds in a rational way or the ability to access the funds they need can be expressed as a minimum cost. When the studies that evaluate the possible effects of financial education are evaluated, it is seen that financial education increases the general savings level of the individual and society, and there is a significant relationship between financial knowledge and financial behaviors and preferences. It has also been shown that financial education seminars cause serious changes in individuals' retirement plans and thoughts. At the same time, it has been observed that training seminars significantly increase the knowledge and equipment of individuals (Gutnu \& Cihangir, 2015: 417; Danışman et al. 2016:7). In parallel with the projects carried out within the scope of financial literacy awareness in many countries; In 2014, the Prime Ministry issued a circular on Financial Access, Financial Education. Protection of Financial Consumer Strategy and Action Plans de in our country. In addition, many organizations have implemented Social and Financial Education through Arts a for children aged 6-14 years (Alkaya et al., 2015: 586). In addition, trainings have been started for housewives who are important pillars of home economy. For example; Provincial Directorates of the Ministry of Family, Labor and Social Services provided financial literacy trainings for housewives in Bilecik (2018), Bolu (2018), Sakarya (2018), Ağrı (2019) and Kahramanmaraş (2019). Financial literacy has been emphasized in the curriculums of higher education institutions. There are many studies in the literature on financial literacy. Some of these studies can be summarized as follows; A study conducted by K1liç and Seyrek in 2015 to determine the financial literacy levels of students studying at Gaziantep University (Kılıç \& Seyrek, 2015: 143.), Dagdelen's 2017 study in Aydın to determine the level of financial literacy of independent accountants and financial advisors (Dağdelen, 2017: vii.), In the study conducted by Karataş in 2017, the study was conducted to increase the financial literacy of children and students (Karataş, 2017: 117-118), OECD (2016), mathematical literacy as a prerequisite for financial literacy (Özkale, 2019: 774.). It will be possible for individuals who have accounting education to determine the risks that may occur in foreign exchange, interest, credit, investment, sales and management issues and take precautions (Karacan, Günce; 2018: 700). Financial statement literacy; to have information about the financial statement, can be expressed as the ability to interpret. When talking about financial 
literacy, it is necessary to mention three basic skills. These are the investigation of accounting information, to evaluate this information and to use this information in a way that is useful for the solution of accounting problems (Wagland, 2009: 14); (Karacan, Journal, 2018: $700)$. Thus, the investors who will make financial decisions will have to take various initiatives as a result of calculating and interpreting the financial ratios that reveal the amounts of the items to be included in the financial statements and the relationship of the items with each other. (URL1)

In this study, questionnaire method was used as data collection method. In order to answer the survey, taxpayers engaged in trade were preferred in Tunceli. The questionnaire forms consist of participant demographic information and basic level of questions about measuring the level of knowledge on finance, retail banking, pension and insurance, financial statements, investment, tax and legislation, mathematics and interest calculations. In the study, a questionnaire was applied to the participants in the time periods that were deemed appropriate after requesting an appointment by telephone. A total of 47 taxpayers with commercial activities were reached. Some of the other taxpayers refused to answer the questionnaire for lack of time. This was the limitation of the study.

According to the findings of the questionnaire and the results of the analysis, the gender of the participants showed a close distribution. Participants were usually young and single; their monthly income is usually 4000 TL and less. Participants generally use credit card and internet banking system. However, they do not prefer the private pension system much. They generally answered correctly the questionnaire posed to the participants. In this context, they are familiar with retail banking, pension and insurance, financial statements and tax-legislation. However, there is a certain level of knowledge in economics and finance (inflation, stock exchange, interest) at a basic level; There is a serious lack of information on investment (bond stock, foreign exchange). The majority of the participants answered the questions about mathematics and interest calculations.

Factors such as business processes, institutionalization efforts of enterprises, expansion of international trade, updating accounting practices (standards, etc.), which have become complicated today, necessitated individuals to act more consciously. In particular, as information technologies dominate the business life, investors have become more difficult to obtain financial information, making their investment preferences more difficult. Therefore, it is inevitable to have some financial information, to manage the budget correctly and to read the financial statements correctly. The concept of financial literacy and financial statements literacy, which has become an important concept in recent years, expresses the attitudes and behaviors of individuals in order to enable them to use their income in a rational way throughout their lives. In this context, individuals have to have a basic level of finance and accounting knowledge in order to evaluate the firm preferences or firms to invest in, or to establish consumption balance and investment balance. In parallel with the international developments in our country, trainings have started to be provided on this subject. In the province of Tunceli, information deficiencies can be eliminated by providing trainings by related institutions on increasing the financial 
literacy and financial statements literacy. In this sense, both nongovernmental organizations and universities can provide trainings to entrepreneurs, housewives, children or individuals who will achieve a balance of consumption savings in order to raise awareness of these individuals.

Keywords: Financial Literacy, Financial Statement Literacy, Financial Behavior.

\section{Giriş}

Toplum içinde yaşayan bireyler günlük yaşantılarını devam ettirebilmek için sahip oldukları kaynakları etkin kullanmalıdırlar. Bu bağlamda hem ihtiyaçlarını karşılamak hem de gelecekte oluşabilecek riskleri minimum seviyeye indirebilmek için tasarruflarını yatırıma dönüştürecek finansal girişimlerde bulunmaktadırlar. Bireyler için bu durum bulundukları bölge, maddi durumlar, nüfus, çalışma ortamı vb. gibi şartlar çerçevesinde değişse de nihai olarak tüm toplum açısından ekonomik sistemi etkileyebilecek boyutlara gelmektedir. Ancak burada esas olan bireylerin verecekleri finansal kararların ne şekilde olacağıdır. Tüketim, tasarruf ve yatırım kararları verebilmek için bu kişilerin muhasebe bilgi sistemine belirli bir düzeyde hâkim olmaları gerekmektedir. Finansal ve mali tablo okuryazarlığı kavramları bu noktada önem kazanmaktadır. Çalışmamız literatür ve uygulama kısmı olmak üzere iki bölümden oluşmaktadır. Literatür bölümünde finansal ve mali tablo okuryazarlık kavramlarına ilişkin genel bilgiler ve bu iki kavram arasındaki ilişki irdelenmiş olup; uygulama bölümünde Tunceli ilinde ticaretle uğraşan vergi mükelleflerinin finansal ve mali tablo okuryazarlık düzeyinin belirlenmesine yönelik uygulama ve sonuçları yer almaktadır.

\section{Finansal Okuryazarlık Kavramı}

Finansal okuryazarlık; bireylerin aldıkları eğitimler sonucunda finansal girişimde bulunmalarını, sahip oldukları fonları rasyonel biçimde kullanabilmelerini veya ihtiyaç duydukları fonlara minimum maliyetle ulaşabilme becerileri olarak ifade edilebilir. Finansal okuryazarlık ilk önce aile ortamında elde edilebilecek bir davranış olduğu düşünülse de günümüz koşullarında çeşitli çalışma ve eğitimlerle bu çaba daha etkin olacaktır. Çünkü finansal okuryazarlığın düzeyinin arttırılmasının ilk basamağı finansal eğitimdir. Finansal eğitim, birey ve toplum üzerinde tasarruf konusunda olumlu bir etki bırakmaktadır. Bu etki genel tasarruf eğiliminin artması ile sonuçlanmaktadır. Bundfan dolayı finansal alanda sahip olunan bilgi ve birikim ile finasal alanda yapılan davranışlar arasında bir ilişki saptanmaktadır. Verilen finansal eğitimlerle bireyler geleceğe dönük kararlarda ve düşüncelerde değişimlerinin olduğu da saptanmıştır. Bu alanda verilen eğitim ve seminerlerle bireylerin finansal bilgi birikimi ve donanımlarını arttırdığı gözlenmiştir. (Gutnu,Cihangir;2015:417; Danışman vd. 2016:7)

Birçok ülkede finansal okuryazarlık farkındalığı kapsamında yürütülen projelere paralel olarak; ülkemizde de 2014 yılında Başbakanlık tarafindan 'Finansal Erişim, Finansal Eğitim, Finansal Tüketicinin Korunması Stratejisi ve Eylem Planları' konulu genelge yayınlanmıștır. Ayrıca birçok kuruluş sosyal proje kapsamında (TEB, MEB, UNICEF vb.) 6-14 yaş aralığındaki çocuklara "Sanat Yolu İle Sosyal ve Finansal Eğitim” konulu etkinliği hayata geçirmiştir. (Alkaya vd. 2015:586.) Ayrıca ev ekonomisini önemli ayağı olan ev hanımlarına yönelik eğitimler verilmeye başlanmıştır. Örneğin; Aile, Çalışma ve Sosyal Hizmetler Bakanlığı İl Müdürlüklerince Bilecik (2018), Bolu (2018), Sakarya (2018), Ağrı (2019), Kahramanmaraş (2019) illerinde ev hanımlarına yönelik finansal okuryazarlık eğitimleri verilmiştir. Yükseköğretim kurumları finans ders müfredatlarında da finansal okuryazarlık konusuna ağılık verilmiştir. 
Finansal okuryazarlık ile ilgili olarak literatürde birçok çalışma mevcuttur. $\mathrm{Bu}$ çalışmalardan birkaçı şu şekilde özetlenebilir; 2015 yılında Kılıç ve Seyrek tarafından Gaziantep Üniversitesi'nde okuyan öğrencilerin finansal okuryazarlık düzeylerinin belirlenmesi amacı ile yapılan çalışmada fakülteler açısından finansal okuryazarlık düzeyinin en yüksek olduğu birimin iktisadi ve idari bilimler fakültesinin olduğu tespit edilmiştir. Bu sonucun öğrencilerin aldığ finans derslerinde elde ettikleri bilgilerden kaynaklandığı belirtilmiştir (Kılıç,Seyrek;2015:143). Dağdelen tarafından 2017 yılında Aydın ilinde serbest muhasebeci ve mali müşavirlerin finansal okuryazarlık düzeyinin tespitine yönelik yapılan çalışmada eğitim ve yaş düzeyinin finansal okuryazarlık düzeyi ile ilişkili olduğu sonucuna varılmıştır (Dağdelen;2017:vii). Karataş tarafından 2017 yılında yapılan çalışmada ise çocuk ve öğrencilerin finansal okuryazarlığının arttırılması amacı ile finansal eğitim kitleri (finansal bilgi kılavuzu, sınıf içi ve dışı öneriler, örnek olaylar), animasyon filmleri, öğretmenlere yönelik bilgilendirme toplantıları, önemli gün ve haftalarda yapılacak etkinlikler, genel ağ sitelerinin oluşturulması konusunda Türkiye Cumhuriyeti Merkez Bankası'na öneriler sunulmuştur. Aynı çalışmada yetişkinlere yönelik öncelikli olarak finansal erişim, finansal tüketicinin hak ve yükümlülükleri konularında elektronik yayınlar hazırlanması konusunda öneriler yer almaktadır. (Karataş;2017:117-118)

Finansal okuryazarlık becerisinin ilişkili olduğu temel becerilerden biri de matematiktir. OECD (2016), matematiksel okuryazarlığı finansal okuryazarlık için bir önkoşul olarak kabul etmektedir. OECD'nin Amerika Birleşik Devletleri'nde uygulanan matematik öğretim programını finansal okuryazarlık penceresinden değerlendirdiği çalışmasında iki okuryazarlık arasında ortak bilişsel beceriler bulunduğunu ve bu becerilerin finansal ve matematiksel okuryazarlik yeterliliklerini beslediğini ifade etmektedir. (Özkale;2019:774) Çünkü analitik düşünmeyi ve kıyaslama becerilerini geliştiren matematik bilimi ile hızlı ve etkin karar verme süreçleri de kolaylaşacak ve yapılacak yatırımın getirisi hesaplanabilmesi için gerekli olan faiz hesaplamaları bireylerin hızlı karar vermelerini sağlayacaktır.

\section{Mali Tablo Okuryazarlığı}

Bilindiği üzere muhasebe; para ile ifade edilebilen iktisadi olayların kaydedilmesi, sınıflandırılması, özetlenmesi ve raporlanması yolu ile işletme bilgi kullanıcılarına tarafsız, doğru ve güvenilir bilgi sunma amacı ile işleyen bir süreçtir. Bu süreçte bahsedilen bilginin kullanılması için bireylerin belirli düzeyde muhasebe eğitimi almış olmaları ve muhasebeye dair temel konular hakkında bilgi sahibi olmaları gerekmektedir. Çünkü muhasebe eğitimi almış bireylerin döviz, faiz, kredi, yatırım, satış ve yönetim konularında oluşabilecek riskleri önceden tespit ederek önlem almaları söz konusu olacaktır. Bunun sonucunda mali tabloları doğru okuyup yorumlayabilmeleri sayesinde sağlıklı kararlar alınacaktır (Karacan,Günce;2018:700). Bu konular aşağıdaki gibi siralanabilir;

-Muhasebenin Temel Kavramları,

-Hesap Kavramı

-Muhasebede Kullanılan Belgeler,

-Muhasebe Raporları,

- Mali Tabloların Biçimi,

-Muhasebe İlkeleri,

-Tekdüzen Hesap Planı,

- Muhasebe Politikalarının Açıklanması,

- Mali Tablo İlkeleri

Turkish Studies - Economics, Finance, Politics

Volume 14 Issue 4, 2019 
Mali tablo okuryazarlığı; mali tablo hakkında bilgi sahibi olma, yorumlama becerisi olarak ifade edilebilir. Herhangi bir finansal girişim için firma borçlanma düzeyi, faaliyet sonucu, karlılı̆̆ 1 , farklı dönem ve işletmelerle kıyaslanması ile ilgili bilgilere ihtiyaç duyulmaktadır. Mali tablo okuryazarlığı; "muhasebe ile ilgili bilginin araştırılması, bu bilgiyi değerlendirebilme ve bu bilgiyi muhasebedeki sorunların çözümünde yarar sağlayacak şekilde kullanabilme" olarak yetenek üzerine kurulmuştur (Wagland;2009:14 aktaran Karacan, Günce;2018:700). Bu bağlamda finansal durum tablosu (Bilanço), kar- zar tablosu (gelir tablosu) ve diğer tabloları anlayarak veya yorumlayarak firma faaliyetleri hakkında bilgi sahibi olunabilir. Fonların rasyonel biçimde yatırıma dönüştürülmesi sağlanabilir. Böylece finansal kararlar alacak olan yatırımcıların mali tablolarda yer alacak kalemlerin tutarlarını ve kalemlerin birbirleri ile olan ilişkisini ortaya koyan finansal oranların hesaplanması ve yorumlanması sonucunda çeşitli girişimlerde bulunması söz konusu olacaktır (URL1).

Mali tablo okuryazarlığı konusunda ülkemizdeki çalışmalar son yıllarda hız kazanmıştır. $\mathrm{Bu}$ bağlamda üniversitelerin ilgili birimleri tarafından mali tablo okuryazarlı̆g 1 ile ilgili çeşitli eğitimler verilmektedir. Literatüre bakıldığında ise konu ile ilgili sınırlı sayıda çalışma olduğu görülmektedir. Söz konusu çalışmalardan biri Karacan ve Günce tarafından 2018 yılında Kocaeli Üniversitesi Meslek Yüksekokulunda muhasebe eğitimi alan öğrencilerin mali tablo okuryazarlığının incelenmesini içermektedir. Bu çalışmada, öğrencilerin temel düzeyde mali tablo okuryazar oldukları ve bu yüzden öğrencilerin mali tabloları anlayabilecekleri uygulayabilecekleri ve bilgilerini aktarabileceklerini düşündükleri sonucuna varılmıştır. (Karacan,Günce;2018:705)

\section{Finansal ve Mali Tablo Okuryazarlığı İlișkisi}

Finansal okuryazarlık ve mali tablo okuryazarlık arasındaki ilişkiye bakıldığında finansal okuryazarlık bireylerin daha küçük yaşlarda öğrenmeleri gereken ve daha sonraki yıllarda aldıkları eğitimle daha profesyonel davranacakları bir süreci ifade etmektedir. Örneğin çocukken biriktirilen harçlıklarla istediği bir eşyayı alması ya da sahip olduğu eşyayı daha verimli kullanması sonucunda toplum içerisinde zevk ve tercihlerinde tasarruf ve tüketim dengesini sağlayarak fayda sağlayabilir. $\mathrm{Bu}$ süreç çocuğun büyüdüğünde ev, araba gibi ihtiyaç duyduğu eşyalar açısından da düşünülebilir. Kısacası finansal okuryazarlık bireyin tüm hayatı boyunca sergilediği finansal tutum ve davranışları kapsamaktadır.

Mali tablo okuryazarlığı ise belirli düzeydeki atıl fonların değerlendirilmesi veya ihtiyaç duyulan fonlara ulaşılabilmesi amacı ile yatırım yapılacak firmanın finansal durumun tespit etmek için mali tabloların anlaşılması becerisidir. Dolayısı ile firmanın ihtiyacı olan fonların geri ödenmesi, maliyeti, elde edeceği getirinin hesaplanması için mali tabloların sağlıklı bir şekilde anlaşılması ve yorumlanması sürecinde mali tablo okuryazarlığı karşımıza çıkmaktadır.

Sonuç olarak; finansal okuryazarlık ve mali tablo okuryazarlığı birbiri ile ilişkili olduğu ve hatta finansal okuryazarlığın mali tablo okuryazarlığını kapsadığı ifade edile edilebilir. Çünkü finansal okuryazarlıkta hem tüketici hem yatırımcı veya fon talebinde bulunan bireyler taraf olurken; mali tablo okuryazarlığında yatırıme veya fon talebinde bulunan bireyler taraf olmaktadirlar.

\section{Tunceli İlinde Ticaretle Uğraşan Vergi Mükelleflerine Yönelik Uygulama}

Son yıllarda birçok ülkede uluslararası kuruluşun finansal okuryazarlığa yönelik farkındalığ 1 arttırmak amacı ile yaptığ 1 çalışmalar büyük bir artış göstermiştir. Ülkemizde de çeşitli kuruluşlar sosyal proje kapsamında finansal okuryazarlığının arttırılması ve bununla birlikte mali tabloların sağlıklı bir şekilde değerlendirilmesi amacı ile çeşitli eğitimler vermektedirler. Tunceli ilinde bahsedilen eğitimlerin verilmediği görülmektedir. Bu noktada çalışmada bu eğitimlere ihtiyaç olup olmadığı da tespit edilmeye çalışmıştır. 
$\mathrm{Bu}$ bölümde önceki bölümlerde yapılan teorik açılamalar çerçevesinde Tunceli ilinde ticaretle uğraşan vergi mükelleflerinin finansal ve mali tablo okuryazarlık düzeyinin tespitine dair değerlendirmeler yer almaktadır. Bu bağlamda Tunceli ilinde finansal ve mali tablo okuryazarlık düzeyinin işletme performansına etkisinin tespiti amaçlanmıştır.

Çalışmada veri toplama yöntemi olarak anket yöntemi kullanılmıștır. Anketin cevaplandırılması konusunda Tunceli de ticaretle uğraşan vergi mükellefleri tercih edilmiştir. Anket formları katılımcı demografik bilgileri ile temel düzeyde ekonomi finans, bireysel bankacılık, emeklilik ve sigortacılık, finansal tablolar, yatırım, vergi ve mevzuat, matematik ve faiz hesaplamaları konulanda bilgi düzeylerinin ölçülmesine yönelik sorulardan oluşmaktadır. ${ }^{1}$

Çalışmada katılımcılara yönelik telefonla randevu talebi sonrasında uygun görülen zaman dilimlerinde anket uygulaması gerçekleşmiş̧ir. Toplamda 47 adet ticari faaliyet gösteren vergi mükellefine ulaşılabilmiştir. Diğer vergi mükelleflerinin bir kısmı zamanlarının olmaması gibi gerekçelerle anketi cevaplamayı reddetmişlerdir. Bu durum çalışmanın kısıtını oluşturmuştur.

\subsection{Tanımlayıcı Bilgiler}

Araştırmaya katılan vergi mükelleflerine ilişkin genel bilgiler aşağıdaki gibidir;

Tablo 1: Tunceli de Ticaretle Uğraşan Vergi Mükelleflerine İlişkin Genel Bilgiler 1

\begin{tabular}{llll}
\hline Vergi Mükellefleri Özellikleri & Gruplar & Frekans & Yüzde \\
\hline Cinsiyet & Erkek & 28 & 59.6 \\
& Kadın & 19 & 40.4 \\
& Toplam & $\mathbf{4 7}$ & $\mathbf{1 0 0}$ \\
& $18-35$ & 26 & 55.3 \\
& $36-52$ & 14 & 29.8 \\
& 53 ve üzeri & 6 & 12.8 \\
& Cevap vermeyen & 1 & 2.1 \\
& Toplam & $\mathbf{4 7}$ & $\mathbf{1 0 0}$ \\
Medeni Hal & Bekâr & 28 & 59.6 \\
& Evli & 18 & 38.3 \\
Aylık Geliri (TL) & Cevap vermeyen & 1 & 2.1 \\
& Toplam & $\mathbf{4 7}$ & $\mathbf{1 0 0}$ \\
& $0-4000$ & 37 & 78.7 \\
& $4001-6000$ & 7 & 14.9 \\
& $6001-8000$ & - & - \\
& 8001 ve üzeri & 2 & 4.3 \\
& Cevap Vermeyen & 1 & 2.1 \\
& Toplam & $\mathbf{4 7}$ & $\mathbf{1 0 0}$ \\
\hline
\end{tabular}

Tablo 1'e bakıldığında Tunceli de Ticaretle Uğraşan Vergi Mükelleflerinin cinsiyet dağılımları birbirine yakındır. \% 55,3 lük bir oranla 18-35 yaş aralığındaki vergi mükellefleri en yüksek paya sahiptir. Bu durumda Tunceli ilinde genç girişimcilerin aktif olduğu söylenebilir. Yakın bir oranda ( \% 59,6) bu girişimcilerin bekâr olduğu da görülmektedir. Aylık gelirlerinin ise $\% 78,7$ 'lik bir oranla 0- $4000 \mathrm{TL}$ aralığında olduğu görülmektedir.

Tablo 2: Tunceli de Ticaretle Uğraşan Vergi Mükelleflerine İlişkin Genel Bilgiler 2

\begin{tabular}{llll}
\hline Bilgiler & Gruplar & Frekans & Yüzde \\
\hline Kredi Kartı Kullanma Durumları & Evet & 34 & 72.3 \\
& Hayır & 13 & 27.7 \\
& Toplam & $\mathbf{4 7}$ & $\mathbf{1 0 0}$ \\
\hline
\end{tabular}

\footnotetext{
${ }^{1} \mathrm{Bu}$ çalışmada kullanılan anket soruları hazırlanırken “Özen Ve Kaya’nın (2015) "Finansal Okuryazarlık Seviyesinin Ölçülmesi; Üniversite Öğrencileri Üzerine Bir Araştırma” İsimli Çalışmasını Aktaran Hark R. (2018) "Üniversite Çalışanlarının Finansal Davranış Analizi: Munzur Üniversitesi Örneği” çalışmasından yararlanılmıştır.
} 


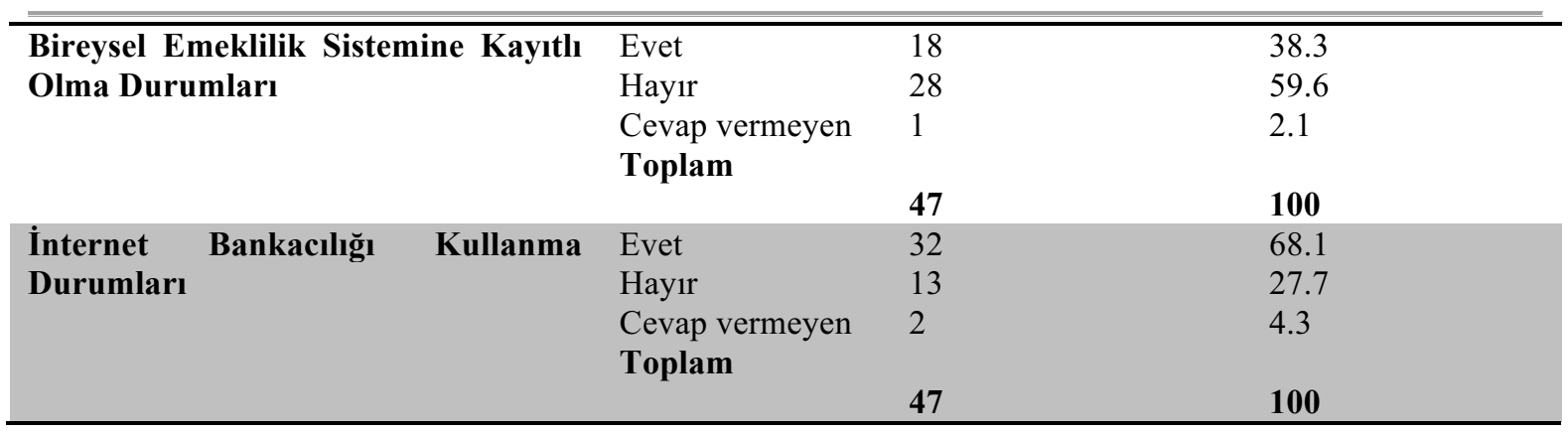

Tablo 2'ye bakıldığında ise Tunceli de ticaretle uğraşan vergi mükelleflerinin büyük bir çoğunluğunun $(\% 72,3)$ kredi kartı kullandığı görülmektedir. Günümüz şartlarında kredi kartının kullanım alanlarının geniş olması ve kısa vadede nakit sıkıntısını gidermesi bakımından alış- veriş ortamında vazgeçilmez hale gelmiştir. Dolayısı ile kredi kartları doğru kullanılması durumunda çok faydalı bir plastik paradır. Vergi mükelleflerinin bireysel emeklilik sistemine $\% 59,6$ 'lık bir oranla kayıtlı olmadığı görülmektedir. Nedenleri sorulduğunda ise gerek duymadıkları, aktaracakları nakite șu an ihtiyaçlarının olduğu ifade edilmiștir. İnternet bankacılık sistemini kullanma durumuna bakıldığında ise \% 68,1'lik bir oranın bu sistemi kullandığ 1 görülmektedir. Bilindiği gibi bilgi teknolojilerinin gelişmesi ile bireyler veya girişimciler birçok işlemi bilgisayar başında hallederek zamanlarını daha etkin kullanma imkânına kavuşmaktadır. Bu bakımdan Tunceli'nin küçük bir il olmasına rağmen; bu ilde ticaretle uğraşan vergi mükelleflerinin zaman yol maliyetlerinden muaf olması ile performansının artması da beklenen bir durumdur.

\section{2. Ölçeklerin Güvenilirliği}

Çalışmanın bu bölümünde Tunceli'de ticaretle uğraşan vergi mükelleflerinin finansal ve mali tablo okuryazarlık düzeyinin tespitine yönelik doğru, yanlış ve fikrim yok yanıtları ile basit faiz hesaplamalarını içeren soru grupları ile ilgili olarak yapılan analiz ve sonuçlara yer verilmiştir.

Çalışmamızda ölçeklerin güvenilirliği konusunda analizler yapılmış olup analizde $\alpha$ olarak ifade edilen oranın 0.70 'ten büyük olması beklenmiştir. Yapılan güvenilirlik analiz sonuçları aşağıdaki tabloda gösterilmiştir.

Tablo 3: Ölçeklerin Güvenilirlik Analizi

\begin{tabular}{lllll}
\hline Ölçek Adı & & & $\begin{array}{l}\text { Madde } \\
\text { Sayısı }\end{array}$ & Alfa Katsayısı \\
\hline $\begin{array}{l}\text { Finansal ve } \\
\text { Okuryazarlığı }\end{array}$ & Mali & Tablo & 32 & 0.725 \\
\hline
\end{tabular}

Çalışmada $\alpha$ değeri 0.725 çıktı̆̆ından ölçeklerin güvenilir olduğu söylenebilir.

\subsection{Hipotezler Çerçevesinde Oluşturulan Sorulardan Elde Edilen Bulgular}

$\mathrm{Bu}$ bölümde finansal ve mali tablo okuryazarlık düzeyi dikkate alınarak hazırlanan soru gruplarına katılımcıların verdikleri yanıtlar yer almaktadır.

Tablo 4: Tunceli'de Ticaretle Uğraşan Vergi Mükelleflerinin Finansal ve Mali Tablo Okur Yazarlığı Unsurları İle İlgili Yanıtları

\begin{tabular}{|c|c|c|c|c|c|c|c|c|c|}
\hline & \multicolumn{2}{|l|}{ Doğru } & \multicolumn{2}{|l|}{ Yanlış } & \multicolumn{2}{|c|}{ Fikrim Yok } & \multirow[b]{2}{*}{$\mathbf{X}$} & \multirow{2}{*}{\multicolumn{2}{|c|}{ Ss }} \\
\hline & $\mathbf{F}$ & $\%$ & $\mathbf{F}$ & $\%$ & $\mathbf{F}$ & $\%$ & & & \\
\hline EKFNS1 & 42 & 89.4 & 2 & 4.3 & 3 & 6.4 & & 2.85 & .465 \\
\hline EKFNS2 & 2 & 4.3 & 39 & 83.0 & 6 & 12.8 & & 1.21 & .508 \\
\hline EKFNS3 & 9 & 19.1 & 26 & 55.3 & 12 & 25.5 & & 1.64 & .792 \\
\hline EKFNS4 & 32 & 68.1 & 8 & 17.0 & 7 & 14.9 & & 2.51 & .777 \\
\hline
\end{tabular}




\begin{tabular}{lrrrrrrrr}
\hline EKFNS5 & 18 & 38.3 & 15 & 31.9 & 14 & 29.8 & 2.06 & .845 \\
EKFNS6 & 32 & 68.1 & 1 & 2.1 & 14 & 29.8 & 2.66 & .522 \\
\hline EKFNS7 & 6 & 12.8 & 33 & 70.2 & 8 & 17.0 & 1.43 & .715 \\
EKFNS8 & 26 & 55.3 & 1 & 2.1 & 20 & 42.6 & 2.53 & .546 \\
\hline BNKCLK1 & 2 & 4.3 & 42 & 89.4 & 3 & 6.4 & 1.15 & .465 \\
BNKCLK2 & 38 & 80.9 & 6 & 12.8 & 3 & 6.4 & 2.68 & .695 \\
\hline BNKCLK3 & 39 & 83.0 & 2 & 4.3 & 6 & 12.8 & 2.79 & .508 \\
BNKCLK4 & 18 & 38.3 & 27 & 57.4 & 2 & 4.3 & 1.81 & .970 \\
\hline BNKCLK5 & 38 & 80.9 & 4 & 8.5 & 5 & 10.6 & 2.72 & .615 \\
BNKCLK6 & 28 & 59.6 & 3 & 6.4 & 16 & 34.0 & 2.53 & .620 \\
\hline EMSGRT1 & 26 & 55.3 & 7 & 14.9 & 14 & 29.8 & 2.40 & .742 \\
EMSGRT2 & 43 & 91.5 & 3 & 6.4 & 1 & 2.1 & 2.85 & .510 \\
\hline EMSGRT3 & 15 & 31.9 & 29 & 61.7 & 3 & 6.4 & 1.70 & .931 \\
\hline EMSGRT4 & 41 & 87.2 & 3 & 6.4 & 3 & 6.4 & 2.81 & .537 \\
\hline EMSGRT5 & 23 & 48.9 & 8 & 17.0 & 16 & 34.0 & 2.32 & .755 \\
FINTAB1 & 33 & 70.2 & 1 & 2.1 & 13 & 27.7 & 2.68 & .515 \\
\hline FINTAB2 & 33 & 66.0 & 3 & 6.4 & 13 & 27.7 & 2.60 & .614 \\
\hline FINTAB3 & 11 & 23.4 & 25 & 53.2 & 11 & 23.4 & 1.70 & .832 \\
\hline FINTAB4 & 13 & 27.7 & 29 & 61.7 & 5 & 10.6 & 1.66 & .891 \\
\hline YTRM1 & 19 & 40.4 & 14 & 29.8 & 14 & 29.8 & 2.11 & .840 \\
\hline YTRM2 & 17 & 36.2 & 17 & 36.2 & 13 & 27.7 & 2.00 & .860 \\
YTRM3 & 25 & 53.2 & 1 & 2.1 & 21 & 44.7 & 2.51 & .547 \\
\hline YTRM4 & 20 & 42.6 & 23 & 48.9 & 4 & 8.5 & 1.94 & .965 \\
YTRM5 & 6 & 12.8 & 33 & 70.2 & 8 & 17.0 & 1.43 & .715 \\
\hline VRGMZT1 & 3 & 6.4 & 42 & 89.4 & 2 & 4.3 & 1.17 & .524 \\
\hline VRGMZT2 & 18 & 38.3 & 26 & 55.3 & 3 & 6.4 & 1.83 & .963 \\
\hline VRGMZT3 & 44 & 93.6 & 2 & 4.3 & 1 & 2.1 & 2.89 & .429 \\
VRGMZT4 & 39 & 83.0 & 3 & 6.4 & 5 & 10.6 & 2.77 & .560 \\
\hline
\end{tabular}

Temel Düzeyde Ekonomi ve Finans (EKFNS) konusunda katılımcıların vermiş olduğu cevaplar şu şekilde özetlenebilir; Enflasyonun paranın satın alma gücünü azalttığına yönelik yöneltilen soruya katılımcıların büyük bir çoğunluğu $(\% 89,4)$ doğru olarak yanıt vermiştir. Bilindiği üzere enflasyon kavramı bir ülkede belirli bir dönem içerisinde fiyatlar genel seviyesinde sürekli artış yaşanması durumudur. Dolayısı ile enflasyonist bir ortamda ihtiyaç duyulan mal ve hizmetlerin daha yüksek fiyatlarda alınıp satılması söz konusu olacaktır. Bu durum paranın satın alma gücünde azalmanın bir sonucudur. Katılımcıların büyük çoğunluğu bu sorulara doğru yanıt vermişlerdir. Türkiye'de enflasyon oranları \%10'un altında olduğuna dair yöneltilen soruya katılımcıların büyük bir çoğunluğu $(\% 83,0)$ yanlış bilgi olarak yanıt vermiştir. "Yanlış" cevab1 doğru olduğundan katılımcılar bu soruya da doğru yanıt vermişlerdir. Anketin uygulandığı ağustos $(\% 15,01)$ ve Eylül $(\% 9,26)$ aylarında meydana gelen değişmelerin etkisiyle bu yanıtın verildiği düşünülmektedir. Enflasyon oranı piyasadaki kredi faiz oranından yüksek ise kredi kullanmanın avantajlı olduğuna dair yöneltilen soruya katılımcıların büyük bir çoğunluğu $(\% 55,3)$ yanlış olarak cevap vermiş; \% 25,5'lik bir oran ise fikri olmadığını belirtmiştir. Bir evi kiralamanın, ev satın almaya kıyasla finansal açıdan bütçeyi daha rahat kullanmayı sağladığını sorusuna \% 68,1'lik oran olumlu yanıt vermiş; yaklaşık \%17'lik bir oranda katılımcılar olumsuz yanıt vermiş; diğer katılımcılar ise fikri olmadığını belirtmiş̧tir. Sabit bir yatırımdan ziyade nakit ihtiyacının kolayca karşılaşacağı bir finansal durumu her girişimci arzu etmektedir. Borsalarda sadece hisse senedi alım-satımı yapıldığı konusunda yönetilen soruya ise katılımcılar yaklaşık oranlarda doğru, yanlış olduğunu ve fikri olmadığı belirtmiştir. Türkiye'deki menkul kıymetler borsasının adı Borsa İstanbul olduğu sorusuna katılımcıların büyük çoğunluğu $(\% 68,1)$ doğru olarak yanıt vermiştir. Daha önceden İstanbul Menkul Kıymetler Borsası olarak faaliyetini sürdüren kuruluş 2013 yılı itibariyle Borsa İstanbul olarak isim değişikliğine gitmiştir. Katılımcıların bu bilgiye hâkim olmadıkları görülmektedir. Vadesiz mevduat hesabı faiz kazancı sağlandığı konusunda yönetilen 
soruya katılımcıların büyük bir çoğunluğu $(\% 70,2)$ yanlış olarak cevap vermiş; Ons, altın gibi kıymetli madenlerin ölçü birimi olduğuna dair yönetilen soruya \% 55,3 lük bir oranla doğru, \% 42,6 lık bir oranda fikri olmadığını belirtmiştir. Bu iki soruya da katılımcılar çoğunlukla doğru yanıt vermişlerdir.

Bireysel Bankacılık (BNKCLK) konusuna yönelik yöneltilen sorulara katılımcılar genellikle doğru olduğu yönünde yanıtlar vermiştir. Örneğin; uzun vadeli kredi kullanmak kısa vadeli kredi kullanmaktan daha maliyetli olduğu \% 80,9; IBAN'IN uluslararası banka hesap numarası olduğu \%83,0; internet bankacılığ 1 yardımıyla kredi başvurusu yapılabildiği \%80,9; internet bankacılığı yardımıyla hisse senedi alım satım ișlemleri yapılabildiği konusunda \% $\% 59,6$ ' ${ }^{\prime} 1 \mathrm{k}$ oranlarda doğru olarak yanıt verilmiștir. Bu bölümde farklı yanıtlar olarak tüm bankaların aynı işlem ücretleri ile çalıştıkları \% 89,4; EFT'nin, aynı bankadaki hesaplar arasında para transferi yapmak için kullanıldığına dair \%57,4 lük oranlarda katılımcılar yanlış bilgi olduğunu belirtmişlerdir. Bilindiği gibi bankalar aynı işlem ücretleri üzerinden çalışmamaktadırlar ve Elektronik Fon Transferi (EFT) kavramı farklı bankalardaki hesaplar arasındaki fon transferini ağlayan sistemdir. Katılımcıların bu konulara kısmen hâkim olduğu görülmektedir.

Emeklilik ve Sigortacılık (EMSGRT) konusunda yöneltilen sorulara katılımcıların büyük çoğunluğu olumlu cevap vermişlerdir. Bireyin yaşının, araç kasko bedelinin belirlenmesinde önemli bir faktör olduğuna \%55,3; SGK'nın (Sosyal Güvenlik Kurumu), Türkiye'de çalışanların bağlı oldukları sağlık güvencesi kurumu olduğuna \%91,5; bireysel emeklilik sisteminin, aylık prim ödemeleri yapılan özel bir emeklilik sistemi olduğuna \%87,2; bireysel emeklilik sisteminde emekliliğe hak kazanmak için 10 yıl süreyle katkı payı ödemesi yapmak gerektiğine katılımcıların çoğunluğu $(\% 48,9)$ katıldıklarını belirtmişlerdir. Ancak Türkiye'de emeklilik yaşı herkes için 65 olduğuna dair \%61.7likbir oran bunun yanlış bir bilgi olduğunu belirtmiştir. Katılımcıların bu bölümdeki sorulara doğru cevap verdikleri ve konuya hâkim oldukları görülmektedir.

Finansal Tablolar (FİNTAB) konusunda ise katılımcılar bilançonun, belirli bir tarihteki varlıkları, borçları ve öz sermayeyi gösterdiği $(\% 70,2)$; öz sermayenin, toplam varlıklarla borçlar arasındaki fark olduğu $(\% 66,0)$ doğru olarak; eğer bir bireyin öz sermaye hesabında 9.000 TL ve borç hesabında $8.000 \mathrm{TL}$ varsa bu bireyin toplam varlıkları 17.000 TL olduğu $(\% 53,2)$; nakit sıkıntısı çeken bir şirketin, kesinlikle zarar ettiğini $(\% 61,7)$ yanlış bir bilgi olarak nitelendirmişlerdir. Katılımcıların bu bölümdeki sorulara da doğru cevap verdikleri ve konuya hâkim oldukları görülmektedir.

Yatırım (YTRM) konusunda katılımcılara yöneltilen sorulara verilen yanıtlara bakıldığında bir şirketin tahvili alındığında o şirkete ortak olunduğu ve hisse senetlerine yatırım yapıldığında faiz kazancı elde edildiği konusunda verilen yanıtların genellikle yakın dağılım gösterdiği görülmektedir. Ancak bilindiği üzere tahvil bir borçlanma senedidir ve bir şirketin tahvilini satın aldığınızda o şirkete borç vermiş olursunuz ancak belirli bir oranda bir şirketin hisse senedini aldığınızda ortak olabilirsiniz. Hisse senedi yatırımı tahvil yatırımına kıyasla daha riskli bir yatırım türü olduğu konusunda katılımcılar yakın oranlarda doğru olduğunu ve fikri olmadığını belirtmiştir. Bilindiği üzere tahviller devletin ya da ticari bir kuruluşun ödünç para sağlamak amacıyla çıkardığı, yıllık belli bir faiz getiren ve alınıp satılabilen değerli kâğıtlardır ve hisse senetlerine kıyasla daha risk taşımaktadırlar. Risk düzeyleri aynı olan iki projeden A projesi B projesinden daha fazla getiri sağlamaktadır. Dolayısıyla iki proje arasından B projesi seçilmesi yönündeki tercihin yanlış olduğunu katılımcıların büyük bir çoğunluğu $(\% 70,2)$ ifade etmiştir. Dövizin, bir tasarruf aracı olduğu konusunda katılımcılar yakın oranlarda bilginin doğru ve yanlış olduğunu belirtmiștir. Döviz kuru ulusal paranın yabancı para birimi karşısındaki değerini ifade eder. Kısaca döviz, yabancı ülke parasına verilen isimdir. Dolayısı ile bireylerin kur değişiminde yararlanarak kazanç elde etmesi söz konusu olsa da döviz genel olarak bir tasarruf aracı değildir. Katılımcıların yatırım konusunda bazı bilgi eksikliklerinin olduğu görülmektedir. 
Vergi ve Mevzuat (VRGMZT) başlığında yöneltilen sorularda alınan cevaplara bakıldığında; katılımcılar Türkiye'de KDV oranı bütün ürünlerde \%18 olarak uygulandı̆̆ $1 \% 89,4)$, yeni bir iş kurmadan önce Sanayi ve Ticaret Odası'na kayıt yaptırmak gerektiği $(\% 55,3)$ bilgisinin yanlış olduğu; her işyeri sahibi vergi dairesine kayıt yaptırmak zorunda olduğu $(\% 93,6)$ ve bir "Vergi Yılı" 1 Ocak'ta başlayıp, 31 Aralık'ta sona erdiği $(\% 83,0)$ bilgisinin doğru olduğu belirtilmiştir. Katılımcıların bu bölümdeki sorulara da doğru cevap verdikleri ve konuya hâkim oldukları görülmektedir.

Matematik ve Faiz Hesaplamaları (MATFAi̇z) konusunda araştırmaya katılan vergi mükelleflerine basit faiz hesaplamalarını içeren sorular yöneltilmiştir.

İlk soru; "Tuna Bey, ayda 2000 TL kazanacağ 1 yeni bir işe girmiştir. Her ay 900 TL kira, 350 TL ulaşım gideri, 500 TL mutfak giderleri ve 100 TL giyinme masrafları vardır. Tuna Bey'in 600 TL para biriktirmesi kaç ay sürecektir?” şeklindedir.

\begin{tabular}{|c|c|c|c|c|c|c|c|c|c|c|}
\hline \multirow{3}{*}{$\underset{N}{2} \cdot \frac{2}{B}$} & \multicolumn{2}{|l|}{ 1ay } & \multicolumn{2}{|l|}{2 ay } & \multicolumn{2}{|c|}{3 ay } & \multicolumn{2}{|l|}{4 ay } & \multicolumn{2}{|c|}{ Fikrim Yok } \\
\hline & $\mathbf{F}$ & $\%$ & $\mathbf{F}$ & $\%$ & $\mathbf{F}$ & $\%$ & $\mathbf{F}$ & $\%$ & $\mathbf{F}$ & $\%$ \\
\hline & 1 & 2.1 & & - & 5 & 10.6 & 36 & 76.6 & 5 & 10.6 \\
\hline
\end{tabular}

Tabloda görüldüğü üzere katılımcıların büyük çoğunluğu 600 TL para biriktirmenin 4 ay süreceğini belirtmiştir. 4 ay cevabını veren katılımcılar doğru yanıt vermişlerdir.

İkinci soru; "Konut kredisinde aylık faiz oranı \%1 ise yıllık faiz oranı ne olmalıdır?" şeklindedir.

\begin{tabular}{|c|c|c|c|c|c|c|c|c|}
\hline \multirow{3}{*}{$\underset{N}{\mathbb{N}} \cdot \frac{3}{3}$} & \multicolumn{2}{|c|}{ \% 12' den az } & \multicolumn{2}{|c|}{$\% 12$} & \multicolumn{2}{|c|}{$\%$ 12' den Fazla } & \multicolumn{2}{|c|}{ Fikrim Yok } \\
\hline & $\mathbf{F}$ & $\%$ & $\mathbf{F}$ & $\%$ & $\mathbf{F}$ & $\%$ & $\mathbf{F}$ & $\%$ \\
\hline & 3 & 6.4 & 26 & 55.3 & 3 & 6.4 & 15 & 31.9 \\
\hline
\end{tabular}

$\mathrm{Bu}$ soruda ise katılımcılar ağılıklı olarak $(\% 55,3)$ yıllık faiz oranının $\% 12$ olacağ cevabını vermiştir. \% 12 cevabını veren katılımcılar doğru yanıt vermişlerdir.

Üçüncü soru; "Banka hesabınızda 100 TL'niz olduğunu ve faiz oranının yıllık \%5 olduğunu varsayın. 1 yıl sonra hesabınızdaki paranın ne kadar olacağını düşünürsünüz?" şeklindedir.

\begin{tabular}{|c|c|c|c|c|c|c|c|c|}
\hline \multirow{3}{*}{$\sim \underset{\mathbf{N}}{\mathbb{2}} \cdot \overrightarrow{3}$} & \multicolumn{2}{|c|}{105 TL' den az } & \multicolumn{2}{|c|}{$105 \mathrm{TL}$} & \multicolumn{2}{|c|}{105 TL' den Fazla } & \multicolumn{2}{|c|}{ Fikrim Yok } \\
\hline & $\mathbf{F}$ & $\%$ & $\mathbf{F}$ & $\%$ & $\mathbf{F}$ & $\%$ & $\mathbf{F}$ & $\%$ \\
\hline & 7 & 14.9 & 23 & 48.9 & 9 & 19.1 & 8 & 17.0 \\
\hline
\end{tabular}

Katılımcılar bu soruya ağırlıklı olarak (\% 48,9) 105 TL cevabını vermiştir. Katılımcıların büyük çoğunluğu bu soruya doğru cevap vermişlerdir. $105 \mathrm{TL}$ cevabını veren katılımcılar doğru yanıt vermişlerdir.

Dördüncü soru; "Banka hesabınızda 100 TL mevduatınız olduğunu farz edin. Yıllık faiz oranı $\% 5$, enflasyon oranı $\% 6$ ise, 1 yıl sonra paranızın alım gücü ne kadar olacaktır?" şeklindedir.

\begin{tabular}{|c|c|c|c|c|c|c|c|c|}
\hline \multirow{3}{*}{$+\mathbb{N} B$} & \multicolumn{2}{|c|}{$100 \mathrm{TL}$} & \multicolumn{2}{|c|}{100 TL'den az } & \multicolumn{2}{|c|}{100 TL' den Fazla } & \multicolumn{2}{|c|}{ Fikrim Yok } \\
\hline & $\mathbf{F}$ & $\%$ & $\mathbf{F}$ & $\%$ & $\mathbf{F}$ & $\%$ & $\mathbf{F}$ & $\%$ \\
\hline & 1 & 2.1 & 23 & 48.9 & 3 & 6.4 & 20 & 42.6 \\
\hline
\end{tabular}

Katılımcılar bu soruya ağırlıklı olarak $100 \mathrm{TL}$ den az $(\% 48,9)$ ve fikri olmadığı $(\% 42,6)$ yönünde cevap vermiştir. $100 \mathrm{TL}$ den az cevabını veren katılımcılar doğru yanıt vermişlerdir. 
Beşinci soru; "Zeynep ve Bilge aynı yaştadır. Zeynep 30 yaşından itibaren her yıl 1.000 $\mathrm{TL}$, Bilge ise 40 yaşından itibaren her yıl $2.000 \mathrm{TL}$ bankaya faize para yatırıyor. 50 yaşına geldiklerinde hangisinin hesabında daha fazla parası vardır?" şeklindedir.

\begin{tabular}{|c|c|c|c|c|c|c|c|c|c|c|}
\hline \multirow{3}{*}{$\frac{2}{N} \cdot \frac{2}{2}$} & \multicolumn{2}{|c|}{ Eşit } & \multicolumn{2}{|c|}{ Bilge } & \multicolumn{2}{|c|}{ Zeynep } & \multicolumn{2}{|c|}{ Zeynep(Blşk) } & \multicolumn{2}{|c|}{ Fikrim Yok } \\
\hline & $\mathbf{F}$ & $\%$ & $\mathbf{F}$ & $\%$ & $\mathbf{F}$ & $\%$ & $\mathbf{F}$ & $\%$ & $\mathbf{F}$ & $\%$ \\
\hline & 24 & 51.1 & 3 & 6.4 & 3 & 6.4 & 7 & 14.9 & 10 & 21.3 \\
\hline
\end{tabular}

$\mathrm{Bu}$ soruda ise \%51,1'lik oranda her iki bireyin eşit miktarda paralarının olacağına dair yanıtlar alınmıştır. "Zeynep. Çünkü birikimleri daha uzun süre bileşik faiz de artmıştır." Cevabını veren katılımcılar doğru yanıt vermişlerdir. Katılımcıların büyük çoğunluğu bu soruya yanlış yanıt vermiştir.

\subsection{Hipotezlerin Analiz Edilmesi}

$\mathrm{Bu}$ bölümde oluşturulan hipotezler ve bu hipotezler doğrultusunda finansal ve mali tablo okuryazarlığını oluşturan unsurların etkinliği ve katılımcıların demografik bilgileri ile finansal ve mali tablo okuryazarlığı arasındaki ilişkinin tespit edilmesi amaçlanmıştır. Bu kapsamda elde edilen veriler korelasyon analizi ve $t$ testi ve Anova testi çerçevesinde değerlendirilmiştir.

Korelasyon analizine kısaca değinecek olursak; bu analiz iki sayısal ölçüm arasında doğrusal bir ilişki olup olmadığını araştırmakta eğer ilişki varsa bu ilişkinin şiddetini ve yönünü bulamay çalışan yöntemdir. Korelasyon katsayısı (r); 0.4-0.6 arasında ise orta şiddette, 0.6-0.8 arasında ise yüksek, 0.8 'den büyük ise çok yüksek korelasyon olduğu yorumu yapılır (URL 2). Verilerin analizinde Pearson korelasyon katsayısı dikkate alınmıştır. Bağımsız gruplar için ise $t$ testi uygulanır. Bu yöntemde de iki grubun ortalamalarının birbirinden farklılığı test edilir. Tek faktörlü Varyans analizi (Analyis of Variance) de ise 3 ya da daha çok grup arasındaki değişkenlerden birinin diğerlerine göre farklılığını belirlemek amacı ile kullanılır (URL 3).

Tablo 5: Vergi Mükelleflerinin Finansal Bilgi düzeyi ile Finansal ve Mali tablo Okuryazarlıkları Arasındaki ilişki

\begin{tabular}{|c|c|c|c|c|c|c|c|c|}
\hline & & 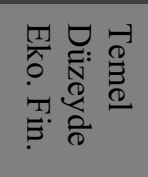 & 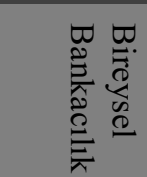 & 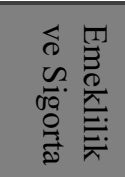 & 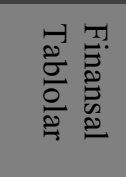 & 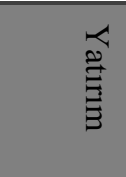 & 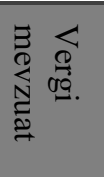 & 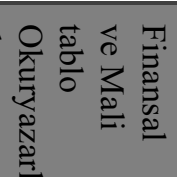 \\
\hline $\begin{array}{l}\text { Temel } \\
\text { Düzeyde }\end{array}$ & $\begin{array}{l}\text { PearsonCorr } \\
\text { elation }\end{array}$ & 1 & & & & & & \\
\hline Ekonomi & Sig. (p) & & & & & & & \\
\hline & $\mathrm{N}$ & 47 & & & & & & \\
\hline $\begin{array}{l}\text { Bireysel } \\
\text { Bankacıllk }\end{array}$ & $\begin{array}{l}\text { PearsonCorr } \\
\text { elation }\end{array}$ & .004 & 1 & & & & & \\
\hline & Sig. (p) & .981 & & & & & & \\
\hline & $\mathrm{N}$ & 47 & 47 & & & & & \\
\hline $\begin{array}{l}\text { Emeklilik ve } \\
\text { Sigorta }\end{array}$ & $\begin{array}{l}\text { PearsonCorr } \\
\text { elation }\end{array}$ & .044 & .277 & 1 & & & & \\
\hline & Sig. (p) & .771 & .060 & & & & & \\
\hline & $\mathrm{N}$ & 47 & 47 & 47 & & & & \\
\hline $\begin{array}{l}\text { Finansal } \\
\text { Tablolar }\end{array}$ & $\begin{array}{l}\text { PearsonCorr } \\
\text { elation }\end{array}$ & -.210 & .059 & .077 & 1 & & & \\
\hline & Sig. (p) & .157 & .694 & .605 & & & & \\
\hline & $\mathrm{N}$ & 47 & 47 & 47 & 47 & & & \\
\hline Yatırım & $\begin{array}{l}\text { PearsonCorr } \\
\text { elation }\end{array}$ & -.109 & $.328^{*}$ & .266 & .115 & 1 & & \\
\hline & Sig. (p) & .465 & .024 & .071 & .443 & & & \\
\hline
\end{tabular}




\begin{tabular}{|c|c|c|c|c|c|c|c|c|}
\hline & $\mathrm{N}$ & 47 & 47 & 47 & 47 & 47 & & \\
\hline \multirow[t]{3}{*}{ Vergi Mevzuat } & $\begin{array}{l}\text { PearsonCorr } \\
\text { elation }\end{array}$ & -.143 & $.302^{*}$ & $.377^{* *}$ & -.072 & $.538^{* *}$ & 1 & \\
\hline & Sig. (p) & .336 & .039 & .009 & .629 & .000 & & \\
\hline & $\mathrm{N}$ & 47 & 47 & 47 & 47 & 47 & 47 & \\
\hline \multirow{3}{*}{$\begin{array}{l}\text { Finansal ve } \\
\text { Mali tablo } \\
\text { Okuryazarlık }\end{array}$} & $\begin{array}{l}\text { PearsonCorr } \\
\text { elation }\end{array}$ & .162 & $.621^{* * *}$ & $.656^{* *}$ & $.291^{*}$ & $.729^{* *}$ & $.648^{* *}$ & 1 \\
\hline & Sig. (p) & .276 & .000 & .000 & .047 & .000 & .000 & \\
\hline & $\mathrm{N}$ & 47 & 47 & 47 & 47 & 47 & 47 & 47 \\
\hline
\end{tabular}

Katılımcıların finans ve muhasebe konularındaki bilgi düzeyleri ile finansal ve mali tablo okuryazarlıkları arasında anlamlı bir ilişki olup olmadığı konusunda yapılan korelasyon analizi sonucunda bireysel bankacılık, emeklilik ve sigortacılık, yatırım vergi ve mevzuat gibi unsurlar ile finansal ve mali tablo okuryazarlığı arasında anlamlı bir ilişki olduğu tespit edilmiştir. Tabloya bakıldığında finansal ve mali tablo okuryazarlık ile bireysel bankacılık, emeklilik ve sigortacılık, yatırım vergi ve mevzuat konuları arasında pozitif yönlü yüksek düzey bir ilisski olduğu; finansal tablolar ile finansal ve mali tablo okuryazarlık arasında ise pozitif yönlü orta düzeyde bir ilissi olduğu görülmektedir.

Tunceli'de ticaretle uğraşan vergi mükelleflerinin demografik bilgileri ile finansal ve mali tablo okuryazarlık genel bilgi düzeyi arasında ilişkinin olup olmadığına yönelik analizler aşağıdaki gibidir;

Tablo 6: Finansal ve Mali Tablo Okuryazarlık Genel Bilgi Düzeyinin Katılımcıların Cinsiyetleri açısından Farklılıkları

\begin{tabular}{|c|c|c|c|c|c|}
\hline $\begin{array}{c}\text { Finansal okur } \\
\text { Yazarlık }\end{array}$ & Cinsiyet & Ortalama & $\begin{array}{c}\text { Standart } \\
\text { Sapma }\end{array}$ & $t$ & $\mathbf{p}$ \\
\hline Genel Bilgi & Erkek & 2.1607 & .17237 & \multirow{2}{*}{$-1,272$} & \multirow{2}{*}{210} \\
\hline Düzeyi & Kadın & 2.2220 & .15482 & & \\
\hline
\end{tabular}

Katılımcıların finansal mali tablo okuryazarlık genel bilgi düzeylerinde, katılımcıların cinsiyetleri açısından istatistiksel olarak anlamlı bir farklılık bulunamamıştır (t:-1,272 ; $\mathrm{p}: 0,210>0,05)$.

Tablo 7: Finansal ve Mali Tablo Okuryazarlık Genel Bilgi Düzeyinin Katılımcıların Yaşları açısından Farklılıkları

\begin{tabular}{|c|c|c|c|c|c|}
\hline $\begin{array}{c}\text { Finansal okur } \\
\text { Yazarlık }\end{array}$ & Yaş & Ortalama & $\begin{array}{c}\text { Standart } \\
\text { Sapma }\end{array}$ & $\overline{\mathbf{F}}$ & $\mathbf{p}$ \\
\hline Genel Bilgi & $18-35$ Yaş & 2.1947 & .16567 &, 352 & $\overline{705}$ \\
\hline \multirow[t]{3}{*}{ Düzeyi } & Aras1 & & & & \\
\hline & 36-52 Yaş Aras1 & 2.1629 & .18146 & & \\
\hline & 53 Yaş ve Üzeri & 2.2292 & .14613 & & \\
\hline
\end{tabular}

Katılımcıların finansal mali tablo okuryazarlık genel bilgi düzeylerinde, katılımcıların yaşları açısından istatistiksel olarak anlamlı bir farklılık bulunamamıştır ( F:,352; p:0,705>0,05).

Tablo 8: Finansal ve Mali Tablo Okuryazarlık Genel Bilgi Düzeyinin Katılımcıların Medeni Durumları Açısından Farklılıkları

\begin{tabular}{cccccc}
\hline $\begin{array}{c}\text { Finansal okur } \\
\text { Yazarlık }\end{array}$ & $\begin{array}{c}\text { Medeni } \\
\text { Durum }\end{array}$ & Ortalama & $\begin{array}{c}\text { Standart } \\
\text { Sapma }\end{array}$ & t & p \\
\hline
\end{tabular}




\begin{tabular}{|c|c|c|c|c|c|}
\hline \multirow[t]{2}{*}{ Genel Bilgi Düzeyi } & Evli & 2.1797 & .18392 & \multirow[t]{2}{*}{,- 267} & \multirow[t]{2}{*}{,791 } \\
\hline & Bekar & 2.1927 & .14549 & & \\
\hline
\end{tabular}

Katılımcıların finansal mali tablo okuryazarlık genel bilgi düzeylerinde, katılımcıların medeni durumları açısından istatistiksel olarak anlamlı bir farklılık bulunamamıştır (t:-,267; $\mathrm{p}: 0,791>0,05)$.

Tablo 9: Finansal ve Mali Tablo Okuryazarlık Genel Bilgi Düzeyinin Katılımcıların Gelir Düzeyleri Açısından Farklılıkları

\begin{tabular}{lllclc}
\hline \multicolumn{1}{c}{$\begin{array}{c}\text { Finansal okur } \\
\text { Yazarlık }\end{array}$} & \multicolumn{1}{c}{ Yaş } & Ortalama & $\begin{array}{c}\text { Standart } \\
\text { Sapma }\end{array}$ & F & p \\
\hline $\begin{array}{l}\text { Genel Bilgi } \\
\text { Düzeyi }\end{array}$ & 0-4000 TL & 2.1791 & .17425 & 1,152 &, 325 \\
& Aras1 & & & \\
& $\begin{array}{l}\text { 4001-6000 TL } \\
\text { Aras1 }\end{array}$ & 2.1652 & .09835 & & \\
& 6001 TL Aras1 & 2.3594 & .24307 & & \\
\hline
\end{tabular}

Katılımcıların finansal mali tablo okuryazarlık genel bilgi düzeylerinde, katılımcıların gelir düzeyleri açısından istatistiksel olarak anlamlı bir farklılık bulunamamıştır (F:1,152; $\mathrm{p}: 0,325>0,05)$.

Tablo 10: Finansal ve Mali Tablo Okuryazarlık Genel Bilgi Düzeyinin Katılımcıların Kredi Kartı Kullanma Durumları Açısından Farklılıkları

\begin{tabular}{|c|c|c|c|c|c|}
\hline $\begin{array}{c}\text { Finansal okur } \\
\text { Yazarlık }\end{array}$ & $\begin{array}{c}\text { Kredi Kartı } \\
\text { Kullanma Durumu } \\
\end{array}$ & Ortalama & $\begin{array}{c}\text { Standart } \\
\text { Sapma }\end{array}$ & $\mathbf{t}$ & $\bar{p}$ \\
\hline Genel Bilgi & Evet & 2.2151 & .14893 & 2,034 &, $048^{*}$ \\
\hline Düzeyi & Hayır & 2.1082 & .19078 & & \\
\hline
\end{tabular}

Katılımcıların finansal mali tablo okuryazarlık genel bilgi düzeylerinde, katılımcıların kredi kartı kullanma durumları açısından istatistiksel olarak anlamlı bir farklılık bulunmuştur. (t:2,034; $\mathrm{p}: 0,048 *>0,05)$.

Tablo 11: Finansal ve Mali Tablo Okuryazarlık Genel Bilgi Düzeyinin Katılımcıların Bireysel Emeklilik Sistemine Katılım Durumları Açısından Farklılıkları

\begin{tabular}{llcccc}
\hline $\begin{array}{c}\text { Finansal okur } \\
\text { Yazarlık }\end{array}$ & $\begin{array}{c}\text { Bireysel Emeklilik } \\
\text { Sistemine Katılım } \\
\text { Durumu }\end{array}$ & Ortalama & $\begin{array}{c}\text { Standart } \\
\text { Sapma }\end{array}$ & t & p \\
\hline Genel Bilgi & Evet & 2.1892 & .17232 &, 163 &, 871 \\
Düzeyi & Hayır & 2.1808 & .16847 & & \\
\hline Independet Samples $t$-Test, ${ }^{*} \boldsymbol{p}<0,05 ; *{ }^{* *}<0,01$ & & & &
\end{tabular}

Katılımcıların finansal mali tablo okuryazarlık genel bilgi düzeylerinde, katılımcıların bireysel emeklilik sistemine katılım durumları açısından istatistiksel olarak anlamlı bir farklılık bulunamamıştır (t:,163; p:0,871>0,05).

Tablo 12: Finansal ve Mali Tablo Okuryazarlık Genel Bilgi Düzeyinin Katılımcıların İnternet Bankacılığı Kullanma Durumları Açısından Farklılıkları

\begin{tabular}{|c|c|c|c|c|c|}
\hline $\begin{array}{c}\text { Finansal okur } \\
\text { Yazarlık }\end{array}$ & $\begin{array}{l}\text { İnternet Bankacılığı } \\
\text { Kullanma Durumu }\end{array}$ & Ortalama & $\begin{array}{c}\text { Standart } \\
\text { Sapma }\end{array}$ & $t$ & $\mathbf{p}$ \\
\hline Genel Bilgi & Evet & 2.1924 & .16269 & \multirow[t]{2}{*}{, 436} & \multirow[t]{2}{*}{,668 } \\
\hline Düzeyi & Hayır & 2.1659 & .19322 & & \\
\hline
\end{tabular}


Katılımcıların finansal mali tablo okuryazarlık genel bilgi düzeylerinde, katılımcıların internet bankacılığ kullanma durumu açısından istatistiksel olarak anlamlı bir farklılık bulunamamıştır (t:,436; p:0,668>0,05).

Yapılan analizler sonucunda hipotezlerin genel değerlendirilmesi ve regresyon modelinin olușturulması șu șekildedir;

\begin{tabular}{|c|c|c|}
\hline $\begin{array}{c}\text { Finansal ve Mali tablo Okuryazarlığı } \\
\text { Unsurları ve Demografik Bilgiler }\end{array}$ & Sonuç & Yorum \\
\hline Temel Düzeyde Ekonomi ve Finans & & \\
\hline $\begin{array}{l}\mathrm{H}_{0} \text { :Temel Düzeyde Ekonomi ve Finans Bilgisi } \\
\text { ile Finansal ve Mali Tablo Okur Yazarlık } \\
\text { Arasında Anlamlı Bir İlişki Yoktur. } \\
\mathrm{H}_{1} \text { : Temel Düzeyde Ekonomi ve Finans } \\
\text { Bilgisi ile Finansal ve Mali Tablo Okur } \\
\text { Yazarlık Arasında Anlamlı Bir İlişki Vardır. }\end{array}$ & $\begin{array}{l}\mathrm{H}_{0} \text { hipotezi } \\
\text { kabul edilir. }\end{array}$ & $\begin{array}{l}\text { Vergi mükelleflerinin temel düzeyde } \\
\text { ekonomi ve finans konuları ile ilgili } \\
\text { bilgi düzeyleri finansal ve mali tablo } \\
\text { okuryazarlığını etkilememektedir. }\end{array}$ \\
\hline
\end{tabular}

Bireysel Bankacilık

$\mathrm{H}_{0}$ :Bireysel Bankacilık ile Finansal ve Mali Tablo Okur Yazarlık Arasında Anlamlı Bir İlişki Yoktur.

$\mathrm{H}_{1}$ : Bireysel Bankacılık ile Finansal ve Mali Tablo Okur Yazarlık Arasında Anlamlı Bir İlişki Vardır.

\section{Emeklilik ve Sigortacilık}

$\mathrm{H}_{0}$ : Emeklilik v Sigortacilık ile Finansal ve Mali Tablo Okur Yazarlık Arasında Anlamlı Bir İlişki Yoktur.

$\mathrm{H}_{1}$ : Emeklilik v Sigortacilık ile Finansal ve Mali Tablo Okur Yazarlık Arasında Anlamlı Bir İliş̧ki Vardır.

\section{Finansal Tablolar}

$\mathrm{H}_{0}$ : Finansal Tablolar ile Finansal ve Mali Tablo Okur Yazarlık Arasında Anlamlı Bir İlişki Yoktur.

$\mathrm{H}_{1}$ : Finansal Tablolar ile Finansal ve Mali Tablo Okur Yazarlık Arasında Anlamlı Bir İlişki Vardır

$$
\text { Yatırım }
$$

$\mathrm{H}_{0}$ : Yatırım ile Finansal ve Mali Tablo Okur Yazarlık Arasında Anlamı Bir İlişki Yoktur. $\mathrm{H}_{1}$ : Yatırım ile Finansal ve Mali Tablo Okur Yazarlık Arasında Anlamı Bir İlişsi Vardır Vergi ve Mevzuat

$\mathrm{H}_{0}$ : Vergi ve Mevzuat ile Finansal ve Mali Tablo Okur Yazarlık Arasında Anlamlı Bir İlişki Yoktur.

$\mathrm{H}_{1}$ : Vergi ve Mevzuat ile Finansal ve Mali Tablo Okur Yazarlık Arasında Anlamlı Bir İlișki Vardır

$\mathrm{H}_{0} \quad$ Katılımcıların cinsiyetleri açısından finansal okuryazarlık düzeylerinde anlamlı bir farklılık yoktur.

$\mathrm{H}_{1}$ : Katılımcıların cinsiyetleri açısından finansal okuryazarlık düzeylerinde anlamlı bir farklılık vardır.

$\mathbf{H}_{0}$ Katılımcıların yașları açısından finansal
Vergi mükelleflerinin bireysel bankacılık işlemleri üzerine bilgi sahibi olmaları finansal okuryazarlık düzeyini arttırmaktadır.
$\mathrm{H}_{1}$ hipotezi kabul edilir.
Vergi mükelleflerinin emeklilik ve $\mathrm{H}_{1}$ hipotezi sigortacılık konularına hâkim bir şekilde kabul edilir. hareket etmeleri finansal ve mali tablo okuryazarlık düzeyleri ile ilişkilidir.
$\mathrm{H}_{1}$ hipotezi

kabul edilir.
Vergi mükellefleri finansal tablolar veya $\mathrm{H}_{1}$ hipotezi muhasebe bilgi sistemini kavrayarak ticari işlemleri gerçekleştirmeleri finansal ve mali tablo okuryazarlığının etkinliği ile mümkün olacaktır.

*Vergi mükellefleri yapacakları herhangi bir yatırım sürecinde finansal ve mali tablo okuryazarlık düzeyinin yüksek olması ile büyük fayda sağlayacaktır.

İşletme bilgi kullanıcılarından devlet mekanizmasının işletme ile vergilendirme sürecini sağlıklı yürütebilmesi açısından vergi mükelleflerinin finansal tablo okuryazarlık düzeyleri önemlidir.
$\mathrm{H}_{0}$ hipotezi Vergi mükelleflerinin cinsiyetlerinin kabul edilir. finansal ve mali tablo okuryazarlığ üzerinde herhangi bir etkisi yoktur.
$\mathrm{H}_{0}$ hipotezi Vergi mükelleflerinin yaşlarının finansal 


\begin{tabular}{lllll}
\hline $\begin{array}{l}\text { okuryazarlık düzeylerinde } \\
\text { farklılık yoktur. }\end{array}$ & anlamlı bir & kabul edilir & $\begin{array}{l}\text { ve mali tablo okuryazarlığ } 1 \text { üzerinde } \\
\text { herhangi bir etkisi yoktur. }\end{array}$
\end{tabular}

$\mathrm{H}_{1}$ : Katılımcıların yaşları açısından finansal okuryazarlık düzeylerinde anlamlı bir farklılık vardır.

Ho $_{0}$ Katılımcıların medeni durumları açısından finansal okuryazarlık düzeylerinde anlamlı bir farklılık yoktur.

$\mathrm{H}_{1}$ : Katılımciların medeni durumları açısından finansal okuryazarlık düzeylerinde anlamlı bir farklılık vardır.

$\mathbf{H}_{0}$ Katılımcıların aylık gelir durumları açısından finansal okuryazarlık düzeylerinde anlamlı bir farklılık yoktur.

$\mathrm{H}_{1}$ : Katılımcıların gelir durumları açısından finansal okuryazarlık düzeylerinde anlamlı bir farklılık vardır.

$\mathbf{H}_{\mathbf{0}}$ Katılımcıların kredi kartı kullanma durumları açısından finansal okuryazarlık düzeylerinde anlamlı bir farklılık yoktur.

$\mathrm{H}_{1}$ : Katılımcıların kredi kartı kullanma durumları açısından finansal okuryazarlık düzeylerinde anlamlı bir farklılık vardır.
$\mathrm{H}_{0}$ hipotezi

kabul edilir
Vergi mükelleflerinin medeni durumlarının finansal ve mali tablo okuryazarlı̆̆ etkisi yoktur.

$\mathbf{H}_{0}$ Katılımcıların bireysel emeklilik sistemine kayıtlı olma durumları açısından finansal okuryazarlık düzeylerinde anlamlı bir farklılık yoktur.

$\mathrm{H}_{1}$ : Katılımcıların bireysel emeklilik sistemine kayıtlı olma durumları açısından finansal okuryazarlık düzeylerinde anlamlı bir farklılık vardır.

$\mathbf{H}_{0} \quad$ Katılımcıların internet bankacılığı kullanma durumları açısından finansal okuryazarlık düzeylerinde anlamlı bir farklılık yoktur.

$\mathrm{H}_{1}$ :Katılımcıların internet bankacılığı kullanma durumları açısından finansal okuryazarlık düzeylerinde anlamlı bir farklılık vardır.

$\mathrm{H}_{0}$ hipotezi Vergi mükelleflerinin aylık gelirlerinin kabul edilir. finansal ve mali tablo okuryazarlığ üzerinde herhangi bir etkisi yoktur.
Vergi mükelleflerinin kredi kartı kullanma durumlarının finansal ve mali tablo okuryazarlığı üzerinde herhangi bir etkisi vardır. Kredi kartlarının sağladığ1 avantajlar ve bilinçli kullanılması ile vergi mükellefleri büyük kazançlar sağlayabileceklerdir.

$\mathrm{H}_{1}$ hipotezi

kabul edilir.
$\mathrm{H}_{0}$ hipotezi

kabul edilir.
Vergi mükelleflerinin bireysel emeklilik sistemine kayıtlı olmalarının finansal ve mali tablo okuryazarlığı üzerinde herhangi bir etkisi yoktur.

Tabloya göre Tunceli'de ticaret ile uğraşan vergi mükelleflerinin finansal ve mali tablo okuryazarlık düzeyini etkileyen konulara genel olarak hâkimdirler. Diğer taraftan bu vergi mükelleflerinin demografik bilgileri (kredi kartı kullanma durumları hariç) ile finansal ve mali tablo okuryazarlık bilgi düzeyleri arasında bir ilişki olmadığı görülmektedir. Vergi mükelleflerinin finansal ve mali tablo okuryazarlık düzeylerinin tespiti amacı ile alınan cevaplar sonucunda oluşturulan regresyon modeli ise şu şekildedir;

$$
\begin{aligned}
& Y_{\text {(FMTOY) }}=0,291 X_{(\text {EKFNS) }}+0,298 X_{(\text {BNKCLK) }}+0,327 X_{(\text {EMSGRT) }}+0,286 X_{\text {(FINTAB })}+ \\
& 0,388 X_{(\mathrm{YTRM})}+\mathbf{0 , 2 8 8 X _ { ( \mathrm { VRGMZT } ) }}
\end{aligned}
$$


Modelde FMTOY finansal ve mali tablo okuryazarlığını; EKFNS temel düzeyde ekonomi ve finans; EMSGRT emeklilik ve sigortacılık; FINTAB finansal tablolar; YTRM yatırım; VRGMZT vergi ve mevzuatı temsil etmektedir. Modelde görüldügü gibi finansal ve mali tablo okuryazarlık düzeyi açısından yatırım ve emeklilik-sigortacılık unsurları daha yüksek bir etkiye sahiptir.

\section{Sonuç}

Günümüzde karmaşık hale gelen iş süreçleri, işletmelerin kurumsallaşma çabaları, uluslararası ticaretin yaygınlaşması, muhasebe uygulamalarının güncellenmesi (standartlar vb.) gibi etmenler bireylerin daha bilinçli bir tavırla hareket etmelerini zorunlu kılmıştır. Özellikle bilgi teknolojilerinin iş yaşantısına giderek hâkim olması sonucunda yatırımcıların finansal bilgileri daha kolay elde etmeleri ile yatırım tercihleri daha zor bir hale gelmiştir. Bu yüzden finansal birtakım bilgilere sahip olmak, bütçeyi doğru yönetmek ve mali tabloları doğru okumak kaçınılmaz bir hal almıştır.

Son yıllarda önemli bir kavram haline gelen finansal ve mali tablo okuryazarlık kavramı bireylerin tüm yaşantıları boyunca gelirlerini rasyonel bir biçimde kullanmalarını sağlamaya yönelik tutum ve davranışları ifade eder. Bu bağlamda bireylerin yatırım yapacakları firma tercihleri ya da firmaların fonları sağlıklı değerlendirmeleri ya da tüketim tasarruf ve yatırım dengesini kurabilmeleri için temel düzeyde finans ve muhasebe bilgisine sahip olmaları gerekmektedir. Ülkemizde uluslararası gelişmelere paralel olarak bu konuda eğitimler verilmeye başlanmıştır.

Çalışma uygulama bölümünde Tunceli de ticaretle uğraşan vergi mükelleflerinin finansal ve mali tablo okuryazarlığı düzeyleri tespit edilmeye çalışmışır. Tunceli de ticaretle uğraşan vergi mükelleflerinin 47'sine ulaşılabilmiştir. Katılımcıların finansal ve mali tablo okuryazarlı̆̆ının etkinliğinin tespitine yönelik hazırlanan anket uygulaması ile elde edilen bulgular ve analiz sonuçlarına göre katılımcıların cinsiyetleri yakın dağılım göstermiştir. Katılımcılar genellikle genç yaşta ve bekâr olup; aylık gelirleri genellikle 4000 TL ve daha düşük tutardadır. Katılımcılar genellikle kredi kartı ve internet bankacılık sistemini kullanmaktadırlar. Ancak bireysel emeklilik sistemini fazla tercih etmemektedirler.

Katılımcılara yöneltilen anket sorularına genellikle doğru cevap vermişlerdir. Bu bağlamda bireysel bankacılık, emeklilik ve sigortacılık, finansal tablolar ve vergi- mevzuat konularına hâkimdirler. Ancak temel düzeyde ekonomi ve finans konularında (enflasyon, borsa, faiz) belirli düzeyde bilgilerinin olduğu; yatırım konusunda (tahvil hisse senedi, döviz) ciddi bilgi eksikliklerinin olduğu görülmektedir. Katılımcıların büyük çoğunluğu matematik ve faiz hesaplamaları konusunda yöneltilen sorulara ise genellikle doğru yanıt vermişlerdir.

Öneri olarak; Tunceli ilinde finansal ve mali tablo okuryazarlığının arttırılması konusunda ilgili kurumlar tarafından eğitimler verilerek tespit edilen bilgi eksiklikleri giderilebilir. $\mathrm{Bu}$ anlamda gerek sivil toplum kuruluşları gerek üniversiteler tarafından girişimciler, ev hanımları, çocuklar veya bir şekilde tüketim tasarruf dengesini sağlayacak bireylere eğitimler verilerek bu bireylerin bilinçlendirilmesi sağlanabilir.

\section{KAYNAKÇA}

Alkaya, A Yağlı, İ. (2015) Finansal Okuryazarlık - Finansal bilgi, Davranış ve Tutum: Nevşehir Hacı Bektaş Veli Üniversitesi İİBF Öğrencileri Üzerine Bir Uygulama, Uluslararası Sosyal Araştırmalar Dergisi Cilt: 8 Sayı: 40 Ekim, s:585-599. 
Danışman, E. Sezer D. Gümüş, T.(2016) Finansal Okuryazarlık Düzeyinin Belirlenmesi: Üniversite Öğrencileri Üzerine Bir Araştırma, Kara Harp Okulu Bilim Dergisi, Aralık, Cilt/26, Sayı:2, $1-37$.

Dağdelen, T. (2017) Finansal Okuryazarlık Düzeyinin Belirlenmesi Ve Aydın İlindeki Serbest Muhasebeci Mali Müşavirler Üzerine Bir Uygulama, Adnan Menderes Üniversitesi Sosyal Bilimler Enstitüsü İşletme Anabilim Dalı (Yüksek Lisans Tezi), Aydın.

Hark R. (2018) Üniversite Çalışanlarının Finansal Davranış Analizi: Munzur Üniversitesi Örneği, Fırat Üniversitesi Sosyal Bilimler Enstitüsü İşletme Anabilim Dalı (Yüksek Lisans Tezi) Elazığ.

Karacan, S. Günce N. (2018), Meslek Yüksekokullarında Mali Tablo Okuryazarlığın Öğrenci Perspektifinden Değerlendirilmesi Uluslararası Sosyal Araştırmalar Dergisi, Cilt: 11, Say1: 58, Ağustos, s:698-706.

Karataş, Ç. (2017) Finansal Okuryazarlığın Geliştirilmesinde Merkez Bankalarının Rolü Ve Türkiye Cumhuriyet Merkez Bankası İçin Bir Değerlendirme, Türkiye Cumhuriyet Merkez Bankası İletişim Ve Dış İlişkiler Genel Müdürlüğü (Uzmanlık Yeterlilik Tezi) Mayıs, Ankara.

Kılıç, Y. Seyrek, İbrahim H. (2015) Finansal Okuryazarlık: Üniversite Öğrencilerine Yönelik Bir Araştırma, Muhasebe ve Finansman Dergisi, Nisan, s:129-150.

Özen E., Kaya Z. (2015) Finansal Okuryazarlık Seviyesinin Ölçülmesi: Üniversite Öğrencileri Üzerine Bir Araştırma, 19. Finans Sempozyumu, 21-24 Ekim, Çorum.

Özkale, A.Erdoğan, E. (2019) Türkiye'de PISA Finansal Okuryazarlık Sorularının Uygulanması: Ön lisans Öğrencilerinin Finansal Okuryazarlık Düzeylerinin Belirlenmesi Örneği, YYÜ Ĕ̈itim Fakültesi Dergisi, ; 16(1),s:771-802.

URL 1 İstanbul Zaim Üniversitesi, Sürekli Eğitim Merkezi (IZZÜSEM), Finansal Tablo Okuryazarlı̆̆ Eğitim Notları, https://www.izu.edu.tr/izusem/egitimlerimiz/finansal-tablookur-yazarl\%C4\%B1\%C4\%9F\%C4\%B1, (03.12.2019)

URL 2 Kul, S. Korelasyon Analizi, http://www.p005.net/analiz/korelasyon-analizi, (05.05.2017)

URL 3 Tek Faktörlü Varyans Analizi (One-Way Anova) ve Bir SPSS Örneği http://www.istatistik.gen.tr/?p=29\#more-29 (07.11.2019) 